\title{
PENGARUH BUNGA DEPOSITO DAN NILAI TUKAR TERHADAP PENDAPATAN PERKAPITA DI INDONESIA (1995-2017)
}

\author{
Francisca Sestri Goestjahjanti \\ STIE Insan Pembangunan \\ E-mail: sestri.rahardjo@gmail.com
}

\begin{abstract}
The purpose of this study is to analyze and assess the magnitude of simultaneously and partially influence of deposit interest and exchange rates to income per capita in Indonesia. This research used secondary data time series for 23 years since 1995 up to 2017. The study method used explanatory research to explain the causal relationship between the variables in a model through hypothesis test. The analyzes employed statistical technique of linear regression with the software E-Views 7 and SPSS-22.The results of the study showed that these variables time deposit rate and xchange rate are simultaneously and partially give significant effects to income percapita in Indonesia period 1995-2017

Keywords : Time deposit rate, Exchange rate, Income per Capita.
\end{abstract}

\begin{abstract}
ABSTRAK
Tujuan penelitian ini adalah untuk menganalisis dan mengkaji besarnya pengaruh bunga deposito dan nilai tukar secara simultan dan parsial terhadap pendapatan perkapita di Indonesia. Data penelitian sekunder runtut waktu selama 23 tahun dari tahun 1995 hingga tahun 2017.Metode penelitian yang digunakan adalah eksplanatori riset untuk menjelaskan hubungan kausal antara variabel yang diteliti dalam suatu model, melalui pengujian hipotesis.Teknik analisis dengan regresi linier, dengan menggunakan software program E-Views 7 dan SPSS-22. Hasil Penelitian secara simultan dan parsial menunjukan adanya pengaruh signifikan antara variabel-variabel bunga deposito dan nilai tukar terhadap pendapatan perkapita di Indonesia periode 1995- 2017.
\end{abstract}

Kata Kunci : Bunga Deposito,Nilai Tukar, Pendapatan perkapita

\section{PENDAHULUAN}

Di era keterbukaan bagi negara-negara dunia ketiga semakin giat dalam perannya di bidang pembangunan manusia dan perekonomian, sehingga diharapkan semua bangsa mengacu pada prinsip pemerataan pembangunan.Dengan demikian antara pemenuhan kebutuhan tiap negara diharapkan pemanfaatan alat-alat produksi secara bijaksana sehingga tercipta suatu pembangunan yang berkelanjutan dari satu generasi ke generasi berikutnya (Development Sustainability).

Konferensi Komunitas Intelektual Terpadu ICONIC 2018 di Hannover menjadi ajang pertemuan para saintis
Indonesia di Jerman dan pengambil kebijakan dalam bertukar wawasan tentang pembangunan berkesinambungan. Hal ini membuktikan negara berkembang sudah mengacu pada prinsip pembangunan berkelanjutan, yang bertujuan terciptanya pemerataan pendapatan antara pusat dan daerah.

Pemerintah Indonesia di bawah kepemimpinan presiden Jokowi, telah berkomitmen penuh di berbagai forum multilateral dan juga kesepakatan internasional. Karena itu, Moeldoko selaku ketua Kantor Staf Kepresidenan, gembira dapat bertukar pikiran dengan perwakilan berbagai badan di Persatuan BangsaBangsa (PBB). Pertemuan tersebut 
membahas opsi-opsi kolaborasi untuk mendorong capaian kesepakatan global yang menjadi fokus bersama sampai dengan 2030 berkait dengan tujuan pembangunan berkelanjutan

Data International Labor Organization (ILO),Indonesia negara besar dengan jumlah penduduk kurang lebih 265,015 juta jiwa di tahun 2018 tersebar di perkotaan 118,1 juta jiwa atau ekuivalen 44,6 persen dan di pedesaan 146,9 juta jiwa atau ekuivalen sebesar 55,4 persen, sehingga pembangunan yang tepat dengan populasi tersebut adalah mengembangkan pembangunan desa mandiri dan bisa menjadi model pengembangan bisnis berkesinambungan (Sustainability Of Business) ungkap salah satu pemateri Budiman Sudjatmiko di Investor Gathering yang diadakan di Jakarta oleh LPER dan Bizcom tanggal 31 Mei 2018.

Menurut Mudrajat Kuncoro, (2010:10), Indikator-indikator kunci pembangunan, secara garis besar pada dasarnya dapat diklasifikasikan menjadi indikator ekonomi (GNI per kapita, DGP per kapita dengan Purchasing Power Parity) dan indikator sosial ( HDI : Human Development Index, dan Indeks mutu
hidup).Tentu indikator tersebut untuk mengukur tingkat kesejahteraan dan kemakmuran penduduk suatu negara.

Namun demikian pendapatan perkapita akan stagnan apabila pertumbuhan ekonomi tidak sesuai target yang ditetapkan, salah satu penyebabnya adalah menurunnya tingkat konsumsi masyarakat Indonesia akhir-akhir ini.

Simpanan deposito jangka panjang atau bentuk obligasi negara, sudah tepat untuk disalurkan sebagai kredit investasi pembiayaan manufacturing atau pembangunan jangka panjang dll. Namun disisi lain negara juga harus mendorong pertumbuhan jangka pendek melalui belanja konsumsi masyarkat. Masyarakat Indonesia dua tahun terakhir giat menyimpan uangnya di Bank dalam bentuk Deposito berjangka pendek, sebagai tindakan kehati-hatian, sehingga menghambat tumbuhnya belanja konsumsi masyarakat dan menekan pertumbuhan ekonomi secara agregat, selanjutnya membuat pendapatan perkapita yaitu PDB per jumlah penduduk tahun ini stagnan. 
Tabel 1. Pertumbuhan Rate Deposito dan Pendapatan Per KapitaIndonesia Tahun $2010-2017$

\begin{tabular}{|c|r|r|r|r|}
\hline TAHUN & $\begin{array}{c}\text { Bunga } \\
\text { Deposito 1 Bln }\end{array}$ & Persentase & $\begin{array}{c}\text { Pendapatan } \\
\text { Per Kapita }\end{array}$ & Persentase \\
\hline $\mathbf{2 0 1 0}$ & 6,500000 & & $27.028 .690,00$ & \\
\hline $\mathbf{2 0 1 1}$ & 6,000000 & $(7,69)$ & $30.658 .980,00$ & 13,43 \\
\hline $\mathbf{2 0 1 2}$ & 5,750000 & $(4,167)$ & $33.531 .350,00$ & 9,37 \\
\hline $\mathbf{2 0 1 3}$ & 7,250000 & 26,09 & $36.508 .490,00$ & 8,88 \\
\hline $\mathbf{2 0 1 4}$ & 6,750000 & $(6,89)$ & $41.900 .400,00$ & 14,77 \\
\hline $\mathbf{2 0 1 5}$ & 6,250000 & $(7,41)$ & $45.176 .200,00$ & 7,82 \\
\hline $\mathbf{2 0 1 6}$ & 5,25000 & $(16,00)$ & $47.960 .000,00$ & 6,16 \\
\hline $\mathbf{2 0 1 7}$ & 4,75000 & $(9,52)$ & $47.980 .000,00$ & 0,05 \\
\hline
\end{tabular}

Sumber: BNI, BPS 2017 (diolah)

Pertumbuhan ekonomi Indonesia diharapkan dari bertambahnya investasi yang berorientasi ekspor. Pada faktanya industri sekarang sangat bergantung dari bahan baku dan barang modal seperti mesin-mesin dari impor, artinya hutang Indonesia dalam valuta asing meningkat. Ketika jatuh tempo akan terpengaruh oleh stabilitas nilai tukar rupiah kita terhadap valuta asing. Maka peran Bank Indonesia diharapkan menjaga benar-benar nilai tukar rupiah terhadap valuta asing, khususnya nilai tukar rupiah terhadap dolar Amerika, yang pada bulan Mei 2018 pernah menyentuh angka USD 1 sekitar Rp. 14.205,- sehingga mendorong kenaikan harga pokok produksi, menekan hasil produksi industrisecara keseluruhan, berdampak pada pertumbuhan PDB Indonesia (Kompas, 8 Juni 2018). Langkah dan terobosan pemerintah sudah tepat disektor pembangunan infrastruktur jangka menengah dan jangka panjang, di sisi lain sangatdiharapkan menggejot lagi belanja masyarakat untuk konsumsi rumah tangga guna meningkatkan pertumbuhan ekonomi, yang pada akhirnya mampu meningkatkan pendapatan perkapita sebagai wujud pemerataan pembangunan berkelanjutan.
Tujuan penelitian ini ditetapkan berdasarkan permasalahan-permasalahan yang paparkan sebelumnya, yakni untuk menganalisis dan mengkaji besarnya pengaruh Bunga Deposito dan Nilai tukar secara parsial dan simultan terhadap Pendapatan Per Kapita di Indonesia

\section{Tinjauan Teoritis}

Produk Domestik Bruto dan Pendapatatan Perkapita

Teori Ekonomi Pembangunan merupakan bagian dari "ilmu ekonomi yang berisikan persoalan-persoalan yang muncul sehubungan dengan adanya masalahmasalah khusus yang terjadi karena transaksi ekonomi antar bangsa yang berdaulat"(Paul R.Krugman 2004: 4). PDB merupakan salah satu indikator penting untuk mengetahui kondisi ekonomi di suatu negara, merupakan nilai produk yang terdiri dari barang dan jasa diproduksi oleh penduduk negara itu dan orang asing yang tinggal di negara tersebut dalam periode satu tahun tertentu. Pengertian Produk Domestik Bruto (PDB) adalah nilai barangbarang dan jasa- jasa yang di produksi di dalam negara tersebut dalam satu tahun tertentu ( Sadono Sukirno 2012 : 34). 
Salah satu komponen dari pendapatan nasional yang selalu dilakukan perhitungannya adalah pendapatan per kapita yaitu pendapatan rata-tara penduduk suatu negara, pada suatu masa tertentu. Menurut Sadono Sukirno (2012 :423- 424), Pendapatan per kapita sebagai pengukur kemakmuran, menunjukkan informasi yang perlu digunakan secara lengkap, menunjukkan taraf kemakmuran dan taraf hidup yang dicapai oleh sebuah negara.Pendapatan per kapita sebuah negara yaitu dengan membagi Produk Domestik Bruto (PDB) satu tahun tertentu dengan jumlah penduduk pada tahun tersebut. Atau membagi Produk Nasional Bruto (PNB) suatu negara satu tahun dengan jumlah penduduk tahun tersebut.

\section{Bunga Simpanan}

Menurut Kasmir ( 2002 : 121) Bunga dapat diartikan sebagai harga yang harus dibayar kepada nasabah yang memiliki simpanan dengan yang harus dibayar oleh nasabah kepada bank yang memperoleh pinjaman. Dengan kata lain bunga bank sebagai balas jasa yang diberikan oleh bank yang berdasarkan prinsip konvensional kepada nasabah yang membeli atau menjual produknya. Menurut teori klasik, tabungan merupakan fungsi dari tingkat bunga pada perekonomian akan mempengaruhi tabungan (saving) yang terjadi. Berarti keinginan masyarakat untuk menabung sangat tergantung pada tingkat bunga. Makin tinggi tingkat bunga, semakin besar keinginan masyarakat untuk menabung atau masyarakat akan terdorong untuk mengorbankan pengeluaran guna menambah besarnya tabungan. Jadi tingkat suku bunga menurut klasik adalah balas jasa yang diterima seseorang karena menabung atau hadiah yang diterima seseorang karena menunda konsumsinya (http://www.landasanteori.com/2015/07/pe ngertian-suku-bunga-dan-teori-faktor.html)

\section{Nilai Tukar}

Menurut Masngudi (2012:2) nilai tukar adalah sistem pembayaran internasional, yang dinyatakan dalam bentuk mata uang suatu negara dengan mata uang negara lainnya yang melakukan transaksi perdagangan internasional yaitu kegiatan ekspor impor. Kurs valuta asing atau kurs mata uang asing menunjukkan harga atau nilai mata uang negara dinyatakan dalam nilai mata uang negara lain. Atau dapat didefinisikan sebagai jumlah uang domestik yang dibutuhkan, yaitu banyaknya rupiah yang dibutuhkan, untuk memperoleh satu unit mata uang asing. (Sadono Sukirno, 2012 : 397). Nilai tukar merupakan kurs yang biasa disebut nilai tukar rupiah terhadap valuta asing, yaitu sistem pembayaran internasional yang dinyatakan dalam bentuk mata uang suatu negara dengan mata uang negara lain. Berkaitan dengan kegiatan ekspor impor nilai tukar ini menentukan bagaimana nilai ekspor suatu negara terhadap nilai impornya.

Sistem pertukaran internasional meliputi 2 (dua) cara :

1. Nilai tukar tertentu. Setiap negara akan mempertahankan cadangan dalam bentuk emas, dolar Amerika Serikat atau mata uang lainnya yang kuat, untuk menjaga stabilitas nilai mata uangnya

2. Nilai tukar fleksibel (mengambang). Sistem ini lebih fleksibel karena sistem dapat mengakomodasi transaksi mata uang yang sangat besar nilainya 
Tabel 2. Penelitian terdahulu yang masih relevan

\begin{tabular}{|c|c|c|}
\hline & Judul Penelitian & Kesimpulan \\
\hline 1. & $\begin{array}{l}\text { Pengaruh Suku Bunga Dan } \\
\text { Pendapatan Perkapita Terhadap } \\
\text { Jumlah Dana Deposito } \\
\text { Berjangka Pada Bank Umum Di } \\
\text { Provinsi Sulawesi Utara Periode } \\
\text { 2009.1-2013.4 } \\
\text { Oleh :Gerry Budiman }{ }^{1} \text {, Robby } \\
\text { Kumaat }^{2} \text { Wensy Rompas }{ }^{3} \text {. } \\
\text { 2016. }\end{array}$ & $\begin{array}{l}\text { Pendapatan perkapita yang semakin } \\
\text { besarakan meningkatkan jumlah dana } \\
\text { deposito pada bank umum di Provinsi } \\
\text { Sulawesi Utara } \\
\text { Tingkat suku bunga secara signifikan } \\
\text { bersifat negatif terhadap deposito } \\
\text { berjangka, oleh karena itu harus } \\
\text { adaperhatian dari lembaga perbankan } \\
\text { dalam menentukan penetapan suku } \\
\text { bunga deposito terutama padadeposito } \\
\text { yang memiliki jangka waktu yang } \\
\text { lebih panjang seperti deposito } \\
\text { berjangka } 12 \text { bulan supayatercipta } \\
\text { kondisi yang senantiasa ideal. }\end{array}$ \\
\hline 2. & $\begin{array}{l}\text { Analisis Pengaruh Pendapatan } \\
\text { Perkapita, Tingkat Suku Bunga } \\
\text { Dan Inflasi Terhadap Jumlah } \\
\text { Tabungan Bank Di Indonesia. } \\
\text { Oleh :Ardilia Savitri, Abdul } \\
\text { Fattah, Haryono. 2016. }\end{array}$ & $\begin{array}{l}\text { Hasil analisis korelasi menunjukkan } \\
\text { nilai R2 dari 0,993. Angka ini } \\
\text { menunjukkan bahwa tingkat } \\
\text { pendapatan per kapita, tingkat suku } \\
\text { bunga dan inflasi mampu menjelaskan } \\
\text { tabungan variabilitas } 99,3 \% \text { sedangkan } \\
\text { sisanya dijelaskan oleh variabel lain di } \\
\text { luar model. Saran yang dapat diberikan } \\
\text { adalah bahwa pelanggan, dan pejabat } \\
\text { bank dan ekonom untuk lebih berhati- } \\
\text { hati ketika membuat keputusan } \\
\text { investasi dengan memperhitungkan } \\
\text { kondisi ekonomi yang ada di } \\
\text { Indonesia. }\end{array}$ \\
\hline 3 & $\begin{array}{l}\text { Income And Population Grwoth } \\
\text { By.Markus Brueckner and } \\
\text { Hannes Schwandt. 2014. }\end{array}$ & $\begin{array}{l}\text { The findings from our instrumental } \\
\text { variables regressions suggest that } \\
\text { countries'income growth has a significant } \\
\text { positive effect on population growth: A } 1 \\
\text { percentagepoint increase in GDPper capita } \\
\text { growth over a 10-year period increases a } \\
\text { country'spopulation growth by around } 0.1 \\
\text { percentage points. At the same time, there } \\
\text { is a significant negative effect on infant } \\
\text { mortality. This results in a strongly positive } \\
\text { effect on surviving children which can also } \\
\text { be detected in changes in countries, } \\
\text { demographic composition. }\end{array}$ \\
\hline 4. & $\begin{array}{l}\text { Pengaruh Kurs Dollar Amerika, } \\
\text { Pendapatan } \quad \text { Perkapita, dan }\end{array}$ & $\begin{array}{l}\text { Hasil uji secara parsial }(\mathrm{t}) \text { yang } \\
\text { menunjukkan, variabel Kurs Dollar Amerika }\end{array}$ \\
\hline
\end{tabular}




\begin{tabular}{lll}
\hline Cadangan Devisa Terhadap & berpengaruh negatif dan tidak signifikan, \\
Impor Kendaraan Bermotor Di & variabel Pendapatan Perkapita dan \\
Indonesia. & Cadangan Devisa berpengaruh positif dan \\
Oleh :I Wayan Agus Indrawan1, & signifikan terhadap Impor Kendaraan \\
Bagus Putu Widanta2. 2015. & Bermotor di Indonesia tahun \\
& $1993-2013$. \\
\hline
\end{tabular}

\section{Kerangka Pemikiran}

Kerangka pemikiran yang dijabarkan dalam bentuk hubungan antara variabel -variabel bebas dengan variabel terikat dalam suatu model penelitian.Penelitian ini menggambarkan hubungan antara variabelvariabel bebas Bunga Deposito (Time deposit) $\left(\mathrm{X}_{1}\right)$ dan variabel terikat Nilai tukar rupiah terhadap dolar Amerika Serikat $\left(\mathrm{X}_{2}\right.$ )yang berpengaruh terhadap Pendapatan Perkapita di Indonesia(Y). Sehingga model penelitian dapat digambarkan sebagai berikut :

Gambar 1. Kerangka Pemikiran

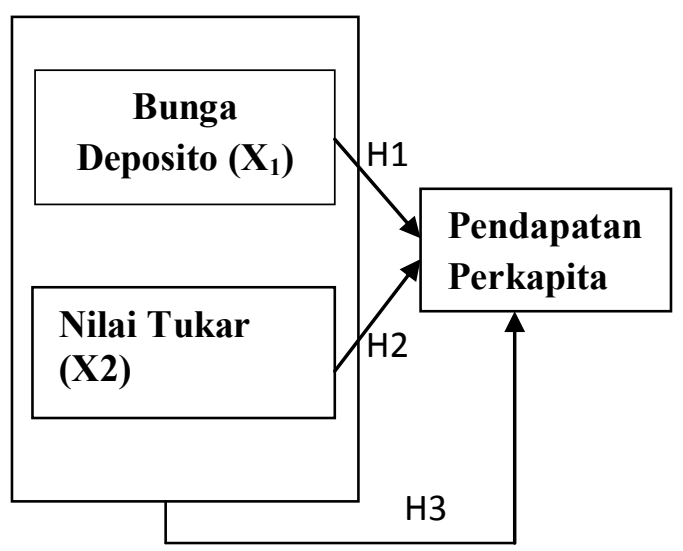

\section{Kerangka Pemikiran Hipotesis}

H1: Terdapat pengaruh signifikan secara simultan antara Bunga Deposito dan Nilai tukar terhadap Pendapatan perkapita di Indonesia

$\mathrm{H} 2$ : Terdapat pengaruh signifikan Nilai Tukar Deposito terhadap Pendapatan perkapita dI Indonesia
H3: Terdapat pengaruh signifikan Nilai tukar terhadap Pendapatan perkapita di Indonesia

\section{METODE PENELITIAN \\ Desain Penelitian}

Menurut Burhan Bungin (2013:53), Desain penelitian mengenai masalah judul penelitian, latar belakang masalah, rumusan masalah, tujuan penelitian, kegunaan penelitian batasan konsep, penentuan variabel indikator, hipotesis penelitian, pengukuran, sumber data, metode penelitian". Desain penelitian pada akhirnya merupakan semua proses yang diperlukan dalam perencanaan dan pelaksanaan penelitian. Pelaksanaan penelitian ini di Jakarta, wilayah Negara Republik Indonesia.

Sumber data :

1. Bank Indonesia

2. Badan Pusat Statistik

3. Bank Negara Indonesia

4. Lembaga terkait

Jenis data sekunder runtut waktu (time series) selama 23 tahun, dari tahun 1995 hingga 2017.Waktu yang dibutuhkan penelitian ini selama empat bulan terhitung dari bulan Maret 2018 s/d bulan Juni 2018.

\section{Definisi Operasional Variabel}

Menurut Burhan Bungin (2013:77), definisi variabel adalah konsep dalam bentuk konkrit atau konsep operasional. Untuk mengoperaionalkan, maka variabel 
harus dijelaskan parameter dan indikatorindikatornya

Batasan-batasan operasional variabel dalam penelitian ini diperlukan untuk menghindari kesalahan dalam pengambilan keputusan. Menurut Sumadi Suryabrata (2016: 48), variabel-variabel yang telah diklasifikasikan itu perlu dibuat definisi operasionalnya.

Bunga Deposito $\left(\mathrm{X}_{1}\right)$ adalah bunga deposito berjangka 1 bulan (Bank BNI : 2017).

Nilai Tukar (X2) adalah kurs atau nilai tukar rupiah terhadap dolar Amerika Serikat yang diambil dari data BI ( kurs tengah BI antara jual dan beli).

Pendapatan perkapita (Y), merupakan pendapatan masyarakat, yaitu perbandingan antara Produk Domestik Bruto /PDB dengan jumlah penduduk suatu negara (Sadono Sukirno : 2012).

\section{Populasi dan Sampel}

Populasi dalam penelitian ini adalah seluruh data bunga deposito berjangka, nilai tukar rupiah terhadap US dolar, dan Pendapatan perkapita di Indonesia. Sampel adalah bagian dari jumlah dan karakteristik yang dimiliki oleh populasi tersebut. Apabila populasi besar dan peneliti tidak mungkin mempelajari semua yang ada pada populasi, misalnya karena keterbatasan dana, tenaga dan waktu, maka peneliti menggunakan sampel yang diambil dari populasi tersebut (Sugiyono, 2014: 81). Sampel dalam penelitian ini sama dengan populasinya.

Metode penelitian dalam penulisan ini merupakan riset ekplanatori (explanatory research) yaitu penelitian menggunakan pengujian hipotesis antara variabel yang memiliki hubungan kausal dalam suatu model. Burhan Bungin ( 2013: 51).

\section{Metode pengumpulan data}

Penelitian ini menggunakan instrumen dokumentasi data melalui internet dari Bank Indonesia, Badan Pusat Statistik dan Lembaga terkait. Untuk kelengkapan penelitian ini juga menggunakan referensi data-data dari literatur, buku-buku, media sosial, internet dan lain-lain penelitian terdahulu.

\section{Uji Asumsi Klasik}

\section{Uji Normalitas}

Berdasarkan hasil perhitugan statistik didapat output bahwa Jarque-Bera $\mathrm{X}_{1}=$ 5,386 dan p-value 0,055 . Jarque-Bera $\mathrm{X}_{2}=$ 20,468 dan p-value 0,36.danJarque-Bera $\mathrm{Y}$ $=5,386$ dan $\mathrm{p}$-Value 0,067 Semua $>$ dari $\mathrm{p}$ value tingkat signifikansi $\alpha=0,05$ maka, semua data yang diuji adalah normal.

\section{Uji Multi Kolinieritas}

Berdasarkan hasil perhitungan statistik didapat output bahwa $\mathrm{R}^{2}$ simultan $92,20 \%$ (tabel 4) > $\mathrm{R}^{2}$ masing-masing variabel independen 56,10\% (tabel 6a) dan 64,10\% (tabel 6b).Maka disimpulkan bahwa model tidak mengandung multikolinier

\section{Uji Heteroskedastisitas}

Melalui uji White didapat output Obs $\mathrm{R}$-square $=0,416>\mathrm{p}$ tingkat signifikansi $\alpha$ $=0,05$ maka model tidak mengandung heteroskedastisitas.

Uji Autokorelasi

Berdasarkan hasil perhitungan satatistik Breusch- Godfrey didapat hasil Obs*R-squared $\mathrm{p}$ value $=0,131>\mathrm{p}$ tingkat signifikansi $\alpha=0,05$, maka model tidak mengadung autokorelasi.

\section{Temuan dan Hasil}

Penelitian ini meliputi analisis dan pengolahan data sekunder mengenai variabel-variabel: Bunga Deposito, Nilai tukaryang disinyalir memiliki pengaruh 
besar dan signifikan terhadap Pendapatan Perkapita Indonesia pada periode tahun 1995 sampai dengan tahun 2017. Dibawah ini disajikan data 10 (sepuluh) tahun terakhir sebagai berikut :

Tabel 3. Bunga Deposito, Ln.Nilai tukar dan Ln. Pendapatan Perkapita Tahun 2007-2017

\begin{tabular}{crcr}
\hline & $\begin{array}{c}\text { Bunga } \\
\text { Dep.Jangka } \\
\text { Wkt 1 bln }\end{array}$ & $\begin{array}{c}\text { Ln Nilai } \\
\text { Tukar }\end{array}$ & $\begin{array}{l}\text { Ln Pend. } \\
\text { Perkapita }\end{array}$ \\
\hline 2007 & 8,000000 & 9,757885314 & 9,074115 \\
\hline 2008 & 10,83000 & 9,969487349 & 9,106727 \\
\hline 2009 & 6,460000 & 10,08083342 & 9,137151 \\
\hline 2010 & 6,500000 & 10,20465417 & 9,18393 \\
\hline 2011 & 6,000000 & 10,33068088 & 9,233688 \\
\hline 2012 & 5,750000 & 10,4202361 & 9,15805 \\
\hline 2013 & 7,250000 & 10,50530012 & 9,188975 \\
\hline 2014 & 6,750000 & 10,64305065 & 9,265379 \\
\hline 2015 & 6,250000 & 10,71832568 & 9,353643 \\
\hline 2016 & 5,25000 & 10,77812261 & 9,353643 \\
\hline 2017 & 4,75000 & 10,77853954 & 9,353643 \\
\hline Sun
\end{tabular}

Sumber : BI dan B.BNI, BPS (2017, diolah)

Hasil analisisi statistik menggunakan Eviews 7 ditampilkan pada tabel 4 .

\section{Uji Koefisien Determinasi}

Hasil perhitungan statistik tabel 4.Didapat $\mathrm{R}^{2}$ sebesar $=0,922$, artinya besarnya pengaruh antara variabel-variabel Bunga Deposito $\left(\mathrm{X}_{1}\right)$ dan Nilai tukar $\left(\mathrm{X}_{2}\right)$ secara simultan terhadap Pendapatan Perkapita di Indonesia(Y) $=92,20 \%$ sisanya $7,80 \%$ dipengaruhi oleh variabel lain diluar model yang diteilti

Tabel 4. Hasil output Eviews

Dependent Variable: LN_PEND_KAP

Method: Least Squares

Date: 03/04/18 Time: 11:51

Sample: 19952017

Included observations: 23

\begin{tabular}{lrlrr}
\hline \hline \multicolumn{1}{c}{ Variable } & Coeffirient & Std. Error & t-Statistic & Prob. \\
\hline \hline \multicolumn{1}{c}{ C } & 1.238136 & 0.846185 & 1.463197 & 0.1590 \\
BUNGA_DEP & -0.036153 & 0.004265 & -8.476486 & 0.0000 \\
LN_NILAI_TUKAR & 0.879069 & 0.091572 & 9.599735 & 0.0000 \\
\hline \hline R-squared & 0.921792 & Mean dependent var & 8.773258 \\
Adjusted R-squared & 0.913971 & S.D. dependent var & 0.653548 \\
S.E. of regression & 0.191690 & Akaike info criterion & -0.344762 \\
Sum squared resid & 0.734905 & Schwarz criterion & -0.196654 \\
Log likelihood & 6.964765 & Hannan-Quinn criter. & -0.307513 \\
F-statistic & 117.8636 & Durbin-Watson stat & 2.260897 \\
Prob(F-statistic) & 0.000000 & & \\
\hline \hline
\end{tabular}




\section{Uji Regresi}

Dari keluaran yang dihasilkan oleh eviews diperoleh persamaan regresi sebagai berikut

$$
\widehat{Y}=1,238-0,036 X 1+0,879
$$

Persamaan regresi diatas menjelaskan pengaruh positif, nilai konstante (C), pengaruh negatif perubahan Bunga Deposito $\left(\mathrm{X}_{1}\right)$ tidak searah dengan perkembangan Pendapatan Perkapita, dan Nilai tukar $\left(\mathrm{X}_{2}\right)$ berbanding searah terhadap perubahan Pendapatan Perkapita Indonesia $\left(\mathrm{Y}^{\wedge}\right)$.

Interpretasi dari model regresi tersebut adalah, apabila variabel $\left(\mathrm{X}_{1)},\left(\mathrm{X}_{2}\right)\right.$ adalah $=$ 0 , maka nilai $\mathrm{Y}$ akan menjadi 1,238 sebesar konstanta. Apabila nilai konstanta dan, $\left(\mathrm{X}_{2}\right)$ $=0$ maka $\left(\mathrm{Y}^{\wedge}\right)$ akan berubah menjadi 0,036x $\left(\mathrm{X}_{1}\right)$, apabila konstanta dan $\left(\mathrm{X}_{1}\right)=0$, maka $\left(\mathrm{Y}^{\wedge}\right)$ akan berubah menjadi $0,879 \mathrm{x}$ $\left(\mathrm{X}_{2}\right)$, asumsi variabel lain adalah seteris paribus.

\section{Uji Hipotesis}

H1: Terdapat pengaruh signifikan secara simultan antara Bunga Deposito dan Nilai tukar terhadap Pendapatan perkapita di Indonesia

Hasil regresi menunjukkan bahwa variabel tingkat bunga (X1) memiliki nilai $t$ hitung sebesar $-8,476$ dengan tingkat singnifikan probabilitas $<0,05$. dengan demikian untuk Hipotesis 1 yang menyatakan terdapat pengaruh yang signifikan dari tingkat bunga deposito terhadap pendapatan perkapita dapat diterima.

H2: Terdapat pengaruh signifikan Nilai Tukar terhadap Pendapatan perkapita dI Indonesia
Hasil regresi menunjukkan bahwa variabel nilai tukar (X2) memiliki nilai t hitung sebesar 9,599 dengan tingkat singnifikan probabilitas $<0,05$. dengan demikian untuk Hipotesis 2 yang menyatakan terdapat pengaruh yang signifikan dari nilai tukar terhadap pendapatan perkapita dapat diterima.

H3: Terdapat pengaruh secara simultan yang signifikan dari Deposito dan Nilai Tukar terhadap Pendapatan perkapita di Indonesia

Nilai F sebesar 117,86 dengan signifikan probabilitas $<0,05$ dengan demikian maka hipotesis model 3, diterima, yaitu secara simultan ada pengaruh signifikan antara variabel Bunga Deposito $\left(\mathrm{X}_{1}\right)$ dan Nilai Tukar $\left(\mathrm{X}_{2}\right)$ terhadap Pendapatan Perkapita di Indonesia (Y).

\section{PENUTUP}

\section{Simpulan}

Berdasarkan hasil analisis data- data sekunder, dan pembahasan yang telah di uraikan maka penelitian ini dapat disimpulkan sebagai berikut.

Terdapat pengaruhsignifikan, hubungan sangat kuat secara simultan antara Bunga Deposito $\left(\mathrm{X}_{1}\right)$ dan Nilai tukar $\left(\mathrm{X}_{2}\right)$ terhadap Pendapatan Perkapita di Indonesia (Y). Besarnya pengaruh secara simultan Bunga Kredit $\left(\mathrm{X}_{1}\right)$ dan Dasar Tukar Ekspor Impor $\left(\mathrm{X}_{2}\right)$ impliksinya kepada PDB Per Kapita Indonesia (Y) sebesar $\mathbf{9 2 , 2 0} \%$ sisanya 7,80 $\%$ dipengaruhi oleh variabel lain diluar model yang diteilti

Terdapat pengaruh signifikan, hubungan kuat, antara Bunga Deposito $\left(\mathrm{X}_{1}\right)$ terhadap Pendapatan Perkapita di Indonesia $(Y)$. b). Besarnya pengaruh variabel Bunga Kredit $\left(\mathrm{X}_{1}\right)$ terhadap PDB Per Kapita di Indonesia (Y) sebesar $\mathbf{5 6 , 1 4} \%$ sisanya 
43,86 \% dipengaruhi oleh variabel lain diluar model yang diteilti.

Terdapat pengaruh signifikan, hubungan sangat kuat variabel Nilai tukar $\left(\mathrm{X}_{2}\right)$ terhadap Pendapatan Perkapita di Indonesia (Y). Besarnya pengaruh Nilai tukar $\left(\mathrm{X}_{2}\right)$ terhadap Pendapatan Perkapita di Indonesia (Y) sebesar $\quad \mathbf{6 4 , 0 8 \%}$ sisanya $35,92 \quad \%$ dipengaruhi oleh variabel lain diluar model yang diteilti.

\section{Saran}

Berdasarkan simpulan hasil penelitian tersebut diatas, maka disarankan hal-hal sebagai berikut :

Penata Ekonomi Makro dan Perbankan menjaga stabilitas nilai tukar dan tingkat bunga deposito, sehingga deposan tidak menahan uangnya terlalu banyak dalam deposito rupiah, dan enggan menambah investasi karena nilai tukar tidak stabil.

Pemerintah dalam hal ini Kementerian Perdagangan harus mampu mendorong investasi berorientasi ekspor dengan membatasi impor barang jadi (non tariff barrier) sehingga dapat membuka lapangan kerja yang dapat mendorong kenaikan pendapatan perkapita masyarakat di Indonesia.

Masyarakat menengah mau membelanjakan uangnya untuk kebutuhan konsumsi maupun investasi di sektor riil.

\section{DAFTAR PUSTAKA}

Buku:

Bungin, Bungin,2013.,Metodologi Penelitian Sosial dan Ekonomi Formar- format Kuantitatif dan Kualitatif, Kencana Prenada Media Group, Jakarta.

Gujarati,Damodar, Gujarati., 2007, Dasardasar Ekonometrika, Penerbit Erlangga, Jakarta.
Kasmir. 2014., Dasar-dasar Perbankan, Edisi Revisi.PT. Raja Grafindo Persada, Jakarta.

Masngudi, 2012.,Ekonomi Internasional Lanjutan, Buku Ajar, FEB UNBOR Jakarta.

Mudrajad Kuncoro. 2010. Dasar-dasar Ekonomi Pembangunan. UPP STIM YKPN, Yogyakarta.

Mukhtar., 2013,Metode Praktis Penelitian Deskriptif Kualitatif, GP Press Group, Jakarta.

Sugiyono., 2014,Metode Penelitian Kuantitatif, Kualitatif, dan $R \& D$, Alfabeta, Bandung.

Sukirno, Sadono., 2012, Makro Ekonomi Teori Pengantar, PT. RajaGrafindo Persada. Jakarta.

Suliyanto., 2011, Ekonometrika Terapan Teori dan Aplikasi dengan SPSSCV.ANDI. Yogyakarta.

Suryabrata, Sumadi., 2016, Metodologi Penelitian, PT. Raja Grafindo Persada. Depok.

Winarno, Wing Wahyu., 2007, Analisis Ekonometrika Dan Statistik dengan Eviews, Yogyakara.

Wirasamita, Yuyun., 2013, "Buku Ajar Metodologi Penelitian" FE Universitas Borobudur Jakarta.

\section{Artikel Jurnal:}

Budiman,Gerry and Kumaat, Robby. et. al., 2016.Pengaruh Suku Bunga Dan Pendapatan Perkapita Terhadap Jumlah Dana DEposito Berjangka Pada Bank Umum Di Provinsi Sulawesi Utara Periode 2009.12013.4, Jurnal.Vol. 16.No.03. FEB Samratulangi, Manado.

Indawan, I Wayan Agus and Widanta, Bagus Putu., 2015, Pengaruh Kurs Dollar Amerika, Pendapatan perkapita, dan Cadangan Devisa Terhadap Nilai Impor Kendaraan Bermotor di Indonesia. Jurnal Ekonomi Pembangunan Vol. 4. No. 5, Mei 2015, FE UNUD, Bali, 
Markus Brueckner and Hannes Schwandt. 2014,INCOME AND POPULATION GROWT, The Economic Journal,2014 Royal Economic Society. Published by John Wiley \& Sons, 9600 Garsington Road, Oxford OX42DQ, UK and 350 Main Street, Malden, MA 02148, USA.

Savitri, Ardilia and Fattah, Abdul. et.al., 2016, Analisis Pengaruh Pendapatan Perkapita, Tingkat Suku Bunga dan Inflasi Terhadap Jumlah Tabungan Bank di Indonesia. Ekonomi Pembangunan, Univ Bhayangkara, Surabaya.

\section{FGD:}

BIZOM \& LPER (Budiman Sudjatmiko), 2018, The Sustainability Of Business:Pemerataan Pembangunan
Desa Mandiri. Investor Gathering, Fairmont Hotel Jakarta, 31 Mei 2018.

Kompas.,8 Juni 2018, Tajuk Rencana : Mengubah Model Pertumbuhan. Jakarta

Website:

Badan Pusat Statistik., 2017, PDB Perkapita ,www.BPS.go.id BNI, 2017, Bunga Deposito (https://www.cermati.com/deposito/bni -deposito)ILO., 2018,Data Penduduk Indonesia.

(http://www.ilo.org/wcmsp5/groups/public/ @asia/@ro-bangkok/@ilojakarta/documents/presentation/wcms 346599.pdf)

Ekonomi.,2017,http://finansial.bisnis.com/r ead/20130718/9/151550/kamus-

ekonomi-apa-arti-suku-bunga-deposito 
Business Management Journal Hasil Penelitian

Vol.14 (No. 2) : 75 - 153. Th. 2018

ISSN: 1907-0896

E-ISSN: 2598-6775 